\title{
WHAT DEFINES THE ROLES OF A JUDGE? FIRST STEPS TOWARDS THE CONSTRUCTION OF A COMPARATIVE METHOD
}

\author{
Kay Goodall, Lecturer in Law, University of Glasgow ${ }^{1}$
}

Judicial roles are changing rapidly in the United Kingdom and the character of judicial decision-making is adjusting alongside. If the impact of Community law is not enough, the implications of devolution and the implementation of the Human Rights Act 1998 should convince any legal theorist that a framework for analysing the altered responsibility of the judge would assist our understanding of what is currently taking place. Academic lawyers have been searching for comparisons to draw from other legal systems but they have sometimes found it difficult to classify their findings in a way which would throw light on the particular circumstances of developments in the United Kingdom. It would be valuable, then, if comparative lawyers were to construct a methodological framework which would allow us to compare judicial roles among legal systems.

There has been a good deal of excellent work carried out on the periphery of this. Within the hermeneutic tradition of legal philosophy, Neil MacCormick, Patrick Atiyah, Robert Summers and the Bielefelder Kreis group have offered comparative analyses of particular aspects of judicial justification. In the field of judicial studies in the United Kingdom, scholars such as John Griffith, Alan Paterson and Robert Stevens have provided contemporary and historical overviews of legal-cultural trends working their way through the decision-making of the higher judiciary. None however provides us with the details of a comparative method by which to analyse the cultural, structural and constitutional roles of the judge at a time of dramatic change.

The task of constructing such a method should not be underestimated. It is not easy to classify the different structural influences in each legal system which set the context for judicial pronouncements and it is even harder to determine, far less predict, the loci of underdetermined areas of decisionmaking which facilitate individual or collective innovation and hence the development of judicial roles. Nevertheless just because this is difficult that is no reason not to be adventurous. Because we need to begin somewhere I will outline some suggestions here for a typology which I have drawn from a variety of works in jurisprudence and comparative political science and which is illustrated with some examples from the United Kingdom and Irish legal systems. I do not, however, pretend to offer a comprehensive framework or a detailed methodology. I say little here about, for example, ethnomethodological or critical/realist studies of judicial roles and even in the relatively structuralist approach I outline here, I should confess to having borrowed more (rather unimaginatively) from mainstream state theories than from alternatives such as cultural or economic theories.

1 Many thanks to Tony Prosser, John Tasioulas and Lindsay Farmer for their comments on earlier drafts of this paper. 


\section{DISTINCTIVE FEATURES OF DEPENDENT LEGAL SYSTEMS AND SMALLER LEGAL SYSTEMS}

\section{Formal independence and socio-economic independence: state and legal system}

First, we need to identify the constitutional status of the legal system and the state to which it belongs. Clearly the higher judiciary in a legal system such as Northern Ireland's, for example, occupy a constitutional role which differs from that of the higher judiciary of Ireland. One is a member of a political and constitutional union of several states while the other possesses legal independence. Ireland's judges are guardians of the Irish Constitution while in most instances the Northern Irish courts are not even the final courts of appeal. The judges of Northern Ireland do not possess the legal authority to make the grand pronouncements which some judges of Ireland have made: there could be no Northern Irish equivalent of the 1960s constitutional case in which the Irish Supreme Court overturned a ban on the importation of contraceptives by evoking a legal concept of "mercy" developed from a reference to Christian charity in the 1937 Constitution. ${ }^{2}$ Clearly, then, the constitutional status of the legal system will influence the character of judicial justification.

We should also remember that, particularly for relatively small or poor nations, economic independence from other nations may not be as complete as political independence. Looking at the two Irelands, we could borrow a classificatory apparatus from comparative political economy, albeit in a rather promiscuous appropriation of the terms. While Northern Ireland may be categorised today as a peripheral nation (if I may categorise it as a separate nation), economically and to some extent culturally dependent on the core nation-state of Britain, Ireland retained for many decades elements of a semi-peripheral status. Late economic development meant that both Irelands depended heavily on UK markets and UK institutions after partition in 1921. The new independent state was less industrialised than its UK and continental neighbours, and despite its avowed political independence from the UK, it remained economically dependent for some time on the UK as its main export market. Even in the $1960 \mathrm{~s}, 75 \%$ of merchandise exports were still sent to the UK. ${ }^{3}$ In the field of commercial law for instance, the Free State used the much greater English experience to fashion their own law of intellectual property and it was not until 1927 that the Free State established its own legislation and acquired its own Patents Office in Dublin: until then Irish traders registered their trade marks on the London Register. ${ }^{4}$ In British Colloids Limited, the nationalist judge George Gavan Duffy said: "we have thought fit very deliberately to adopt and continue the British Trade mark system, and... to consult the English decisions". ${ }^{5}$ In these circumstances the need for free flow of trade limited the freedom of both Irish judiciaries to

2 McGee v Attorney General [1974] IR 284, 318.

3 See the Department of Enterprise and Employment website at www.entemp.ie/ireland.htm.

4 Tierney, Irish Trade Marks Law and Practice (1987) pp xxiii, xxiv and 14.

5 British Colloids Ltd $\mathrm{v}$ The Controller of Industrial and Commercial Property [1943] IR 56, 68; also quoted in Tierney, ibid p xxiii. 
develop a distinctive strand of precedent in commercial law. Here, there would have been little space for judicial innovation and the absence of distinctive judicial justification would not necessarily have implied judicial conservatism.

Smaller legal systems may choose to seek legislative harmony with their larger neighbours for cultural as well as economic reasons. Some have had the legal system of their neighbours forced upon them and have never subsequently replaced it. Northern Ireland of course shares its law in many respects with England and with the rest of the UK. In Ireland, many of the old English statutes remained in place even after the English had repealed them and some, such as the Offences Against the Person Act 1861 and the Larceny Act 1916 are still in force today. Many of the newer statutes are modelled on English statutes ${ }^{6}$ and Ireland has sought the advice of English lawyers when drawing up new statutes: Glanville Williams for instance acted as a consultant for the Civil Liability Act of 1961. ${ }^{7}$ The Irish Law Reform Commission has chosen to take a harmonising approach in its reports on the updating of the substantive law and it has sought to recommend changes in Irish law which would be in keeping with the developments in other nations, particularly England. All these factors will be influential on the character of judicial justification in shared areas of law; judicial reasoning does not take place entirely sheltered from the socio-economic framework of law.

We should also not forget the huge influence of European Community law on all the members of the European Union. None of the member states is entirely free from that substantive and jurisprudential influence on judicial reasoning and no analysis of judicial justification could afford to ignore its sovereign power.

\section{Formalism and the smaller legal system}

Legal and socio-economic independence are one strong influence on the freedom of individual legal systems to develop distinctive roles for their judiciaries. The relative size of the legal system is another. This may influence characteristics of law in that system which at first glance might seem to have little to do with such matters as territory, population size or aspects of demography. I can explain this observation best through using an example.

Atiyah and Summers, in their outstanding study of formal and substantive reasoning in the UK and the United States, ${ }^{8}$ introduce the concept of mandatory formality. Unlike substantive reasons, which look to the rights of the parties to a case or the consequences of a judicial decision, formal reasons in law depend for their validity on the institutional status of the rule from which they originate. When a choice must be made between competing reasons, an applicable formal reason has in the normal run of things a mandatory force (mandatory formality). It will prevail over any contrary

6 Compare the Trade Marks Acts of 1938 in England and 1963 in Ireland, or the updated Interpretation Act in Ireland.

7 McMahon, "The Irish Contribution to Tort Law" 4 Dublin University Law Journal (1982) 1, pp 9-10.

8 Atiyah and Summers, Form and Substance in Anglo-American Law (1987). 
substantive reason that would otherwise decide the case. High mandatory formality, when it genuinely exists, makes the law more certain and predictable. $^{9}$

Atiyah and Summers do not explore the question of population size in a legal system, but it could be argued that a slightly lower degree of mandatory formality is necessary in small independent legal systems, all else being equal, than would be the case in larger legal systems, because there is far less threat in a small legal system from a multiplicity of future cases which would make strict delineation of rules necessary from the outset. We might therefore predict that there would be a little more scope for substantive reasoning and less of a need for definitive decision-making in the small legal system - as indeed we find in the later half of the twentieth century in Ireland in cases such as The State (Nicolau) v An Bord Uchtála, where Walsh J insisted that Article 40.3 of the Irish Constitution expressly subordinates law to justice in the form of natural rights, ${ }^{10}$ and in the not-so-distant past in Scots criminal law, where there is a history of "special" verdicts in exceptional cases. ${ }^{11}$

It is only in recent years, as the smaller legal systems have increasingly given up legal sovereignty to European legal systems and have increasingly delegated political decision-making to international economic organisations, that jurists and legal decision-makers in these smaller systems have begun systematically to reconsider the pockets of low formality the systems possess. If we consider the proposition that the size of a legal system is in some way linked to the degree of importance of mandatory formality, we could suggest that until recently rules in Ireland and Scotland would have had high mandatory formality in the ordinary run of things but there would have been room for extraordinary development of the law without serious disruption to the regulation of society. Such freedom would have had a chaotic effect in the larger English legal system with its high turnover of cases on contested issues. ${ }^{12}$

These observations are only examples and it might be when a broader range of legal phenomena is compared to similar phenomena in a larger legal

9 Ibid, 27.

10 The State (Nicolau) v An Bord Uchtála [1966] IR 567. The remark was obiter but was of great influence subsequently for over two decades. See also the discussion of "mercy" in McGee v Attorney General [1974] IR 284, cited above. Consider too, as an illustration of this argument, McMahon's comparison of English and Irish tort law in "The Irish Contribution to Tort Law" (1982) 4 DULJ 11.

11 See $e g$ the automatism decisions of Simon Fraser (1878) 4 Coup.70 and HMA v Hayes 1949 (unrep.); extracts in Gane and Stoddart, A Casebook on Scottish Criminal Law ( $2^{\text {nd }}$ ed., 1988). On this topic generally, and several others raised in this article, see also the discussion in Farmer, "'The Genius of our Law. . .' Criminal Law and the Scottish Legal Tradition" (1992) 55 MLR 25.

12 Atiyah and Summers do suggest that the enormous volume of case law in the US produces a less formal legal system and that Americans are "to some degree. . . comparative lawyers" ( $n 10$ above, $\mathrm{p}$ 130), but the difference here seems to be that the English legal system is both large enough to produce repeated appeals on a single topic and small enough that the practising lawyer and academic can keep abreast of all the relevant decisions - an impossible task in America, even with the help of electronic searches. 
system, that the proposition does not hold when tested. Nevertheless it would be interesting to experiment with it.

\section{Ascriptions of idiosyncrasy and the smaller legal system}

Differentiation by population size between small and large legal systems, crude as it is, tends to be overlooked or misunderstood by commentators outside the small systems. There is a tendency in particular to see the larger systems (for instance, those of England and the UK) as providing some form of objective standard by which to evaluate "local" differentiation. ${ }^{13}$ Together, these impressions (which are incompletely articulated) make surviving norms and institutions in smaller legal systems such as those in Scotland and Ireland seem anachronistic, while new norms and institutions appear to be peripherally "ethnic". ${ }^{14}$

While it may be reasonable, for example, to acknowledge that the development of the law of Ireland has been heavily influenced by Catholic doctrine, it is unjustifiable to presume that this makes its law particularistic and therefore lacking in the universalisable qualities which would allow it to contribute to international debate. There is a risk of making easy connections between Catholicism and particular features of the law of Ireland as if this provided sufficient explanation for elements of law which have replaced the parent English. Taking an example, we can observe that the judiciary in Ireland claims to retain the power to declare new crimes. ${ }^{15}$ This is a power which implies that certain moral norms possess a fundamental legal authority in that system but it would be poor scholarship to regard this as simply a consequence of the influence of a strong Catholic church. Scotland, for some decades a predominantly secular society with a Protestant state church, has never formally abandoned the declaratory power either. ${ }^{16}$ Furthermore Scotland still retains an interpretative approach in the criminal law which is arguably as strongly allied to the twin principles of moral blameworthiness and public protection as it is to the often conflicting principle that law should be clear and precise. Distinctive law in smaller legal systems is vulnerable to

13 As Farmer has pointed out, lawyers in the small legal systems may unwittingly reinforce this belief by responding with a form of resistance which promotes an ossified vision of local law: see his comments in "Debatable Land: An Essay on the Relationship Between English and Scottish Criminal Law" (1999) 3 Edinburgh Law Review 32.

14 See $e g$ the pointed complaint of Whelan in his concluding chapter in a collection of essays, Values and Social Change in Ireland (1994), p 212: "The cultural consequences of the particular Irish experience of modernisation cannot be understood in terms of a logic of development in which the Irish value profile inexorably moves nearer to that typical of more 'advanced' societies."

15 Hamilton J in Attorney General (SPUC) v Open Door Counselling Ltd [1988] IR 593.

16 There is a considerable body of case law on the subject and the most recent decision in which the power was discussed is Grant v Allan 1988 SLT 11, 14. It is unlikely however that it could be exercised today in Scotland and survive a challenge under the Human Rights Act 1998 because it offends against the principles of clarity and non-retrospectivity in the criminal law. The Human Rights Act in its narrowest construction binds only legislation of the Scottish Parliament until the statute is implemented in full in October 2000, but Convention rights are being much more widely cited in a flood of litigation. 
the marginalising effect of cultural hypotheses which are presumed and left unstated but never proved.

Perhaps a particularly striking example can be found in the debates in Ireland over the relationship between Irish constitutional law and rights of sexual privacy and the law of homosexuality. The Supreme Court has at different times drawn a distinction between the right to privacy within a sanctioned union (even to engage in acts which are contrary to the principles of the Catholic church, which at that time occupied a special position under the Constitution) and the right to privacy within relationships thought to undermine the common good. The first was held in 1967 to be worthy of constitutional protection; ${ }^{17}$ the latter, in 1993, was held not. ${ }^{18}$ The decisions were widely debated and were examined in both national and international journals ${ }^{19}$ but were predominantly - and of course legitimately - analysed within the framework of a Christian constitution which was explicitly imbued with scholastic principle. These analyses seem methodologically neutral yet their effect is insidious. Because of the narrow parameters of the debate, the decisions come to seem distinctively Catholic, distinctively Irish, systemically particularistic rather than globally universalisable.

It comes as a surprise, then, to compare an analysis of two rather similar North American cases by Michael Sandel. Sandel writes with great insight about two Supreme Court decisions in the United States, contemporaries of the Irish cases, ${ }^{20}$ also dealing first with marital privacy and later with homosexuality, which also reached conclusions based on sanctioned union and social morality rather than on individual liberty or rights of expression. It is by examining Sandel's analysis that we can recognise the presumptions unwittingly promoted by the Irish analyses. Sandel writes for an international audience for whom the principles of which he speaks are embedded in a supranational history of ethical argument. He speaks of Western tradition, liberal moral neutrality and substantive moral discourse in communitarian thought. He never considers that the North American decisions could reflect a peculiarly North American morality - and so neither does the typical reader.

17 McGee v Attorney General [1974] IR 284, cited above regarding decisions based on "mercy".

18 Norris v Attorney General [1984] IR 36.

19 Even the most jurisprudential analyses seem trapped within a vision of parochialism. Clarke's article, "The Role of Natural law in Irish Constitutional Law" (1982) 17 Irish Jurist 187, is an excellent critique of the defects of natural law reasoning in McGee and other cases which does not however treat Irish constitutional law as a body of norms which could be placed anywhere on a spectrum of thought in Western constitutional jurisprudence. O'Connell's piece, "Natural Law: Alive and Kicking? A Look at the Constitutional Morality of Sexual Privacy in Ireland" (1996) 9 Ratio Juris 258, makes many insightful remarks about liberalism and morality in the Norris decision but nevertheless confines itself again largely to a critique of the scholastic claims made in that case and others.

20 Poe v Ullman 367 US 497 (1961) (marital privacy) and Bowers 478 US 186 (homosexuality). Sandel, "Moral Argument and Liberal Toleration: Abortion and Homosexuality" in A. Etzioni, New Communitarian Thinking (1995) pp 71-87. 
All too easily to their critics, Irish judges could come to appear as casuists purveying nothing more significant than sectional interests, while North American judges even at their worst are not marginalised because they nevertheless remain as participants (however flawed) in central debates in Western ethical argument. This is not an unimportant result. Judicial justification is exposed to differential cultural analyses and the search for a genuinely comparative study is lost. It is in this way that hidden methodological assumptions act to close down legal imagination and to marginalise legal developments in smaller legal systems so that we focus our search for law's futures solely on larger legal systems which already benefit from not just more but disproportionately more academic interest.

\section{Ascriptions of cultural homogeneity and the smaller legal system}

The assertions above are sweeping and undoubtedly difficult to prove. There are features of smaller legal systems which are easier to identify and compare. We may find, for instance, in smaller legal systems that the judiciaries maintain an appearance of consistency and coherence in their reported judgments over long periods of time when we compare the bodies of decisions to those of larger legal systems. This is a phenomenon which can be found in the Northern Ireland Court of Appeal and the Irish Supreme Court when compared to the English Court of Appeal and the UK House of Lords and is easily verified by looking at particular areas of law in each jurisdiction. To take only one example we could look at the law of recklessness in English and Irish law. The Irish Law Reform Commission was not afraid to state that the one fundamental test of intent in criminal law in Ireland is a subjective test based on the perceptions of the individual accused. ${ }^{21}$ In English law there seem to be almost as many conceptions of the "subjective" and "objective" tests as there are cases in which definitions of the terms occur. The topic is bewilderingly complex and when I was examining it for a comparative study I was more than grateful to the Northern Irish jurist John Stannard who helpfully classified the formulae of the English caselaw within a mere four definitions of recklessness. ${ }^{22}$

If this could be explained by doctrinal homogeneity, then it would clearly be significant in a study of the political and constitutional significance of judicial justification. However, we need to consider other structural factors before relying upon this assumption as evidence of consensus. In Ireland in particular, there may indeed be a high degree of societal consensus which rests on the social homogeneity of Ireland ${ }^{23}$ and also on the smaller

21 Law Reform Commission, Non-Fatal Offences Against the Person (1994) 10. likewise in Scotland a putatively objective test of recklessness has been left as undisturbed by caselaw: the Scots test appears in many judicial formulations but these are little more than reformulations and the concept behind the test has not been attacked.

22 Stannard "From Andrews to Seymour and back again" (1996) 47 NILQ 1.

23 The population remains around $92 \%$ Catholic and is very largely of Irish origin. Of a population of 3.5 million, 3.2 million professed themselves Catholic in the 1991 survey cited in the 1994 Ireland Statistical Abstract. Immigration from any other nation remained at very low levels until the 1990s. 
population and tight-knit legal community. ${ }^{24}$ However one alternative explanation for the comfortingly integrated appearance of Supreme Court decisions lies in the operation of the courts themselves and the frequency with which cases have come before them.

\section{(a) Variation in judicial panels}

In smaller legal systems, the size of the higher judicial body may be no greater than the size of the typical multi-judge panel in a case on appeal to the Supreme Court. In Ireland until reorganisation in 1995, increasing the size of the court, ${ }^{25}$ it was effectively the case that every case with constitutional implications that came before the Supreme Court was decided by the full Court. In Northern Ireland until the creation of a fourth post in 1975 there were only three members of the Court of Appeal at any one time, including the Lord Chief Justice, so all major cases coming before the court were in effect decided by the full court. This has minimised one cause of inconsistency that the House of Lords must face: conflicting or subtly different decisions on the same subject by a differently constituted House sometimes within weeks of the first decision. ${ }^{26}$ A decision of the Supreme Court or the Northern Ireland Court of Appeal may of course contain internal inconsistencies in its judgments where more than one is published, but there is much less often the problem of weighing one case against another. There has also been notable longevity in the period of service among the higher judiciary in both Irelands. This has enabled individual judges to make a significant contribution over a period of time. In Northern Ireland, Clive Walker has remarked that Lord Lowry "was Chief Justice between 1971 and 1989 and therefore by this accident of timing was arguably by far the most important ever Supreme Court judge in the history of Northern Ireland". ${ }^{27}$

The only source of variety in these legal systems would be the temporary elevation of a lower judge to stand in where a member of the supreme court was unavailable to hear a case. This does of course happen frequently in some legal systems, but the researcher would then need to investigate whether the elevated judge in any particular case felt that he or she possessed the necessary authority to sway the opinion of the panel or to provide a hardhitting dissent.

24 This last factor is not necessarily determinative, though: Bridges et al have found in their empirical study of cases referred for judicial review that assigning cases to a smaller cadre of judges does not automatically result in greater consistency in decision-making: Judicial Review in Perspective (1995), p 189 and ch 8. See also Doran and Jackson in Dawson and Ingram One Hundred and Fifty Years of Irish Law (1996), pp 79-83 on the closer working relationship between bar and bench in both Irish legal systems when compared to England.

25 Byrne and McCutcheon, The Irish Legal System ( ${ }^{\text {rd }}$ ed, 1996), p 97.

26 See eg $R$ v Caldwell [1982] AC 341 and $R$ v Lawrence [1981] 1 All ER 974, two House of Lords decisions on criminal recklessness reached only weeks apart.

27 C. Walker, "Emergency cases: Commissions, Commissioners and the commodity of justice", Conference on the Judicial Role in Criminal Proceedings, Belfast 1998. See also Walker's assessment in "The commodity of justice in states of emergency" (1999) 50 NILQ 164. Lord Lowry died in 1999. 


\section{(b) Low frequency of case turnover}

Judicial consistency can also be misleadingly implied by the phenomenon of low frequency in which cases come before the higher courts. The relatively low frequency with which cases and particularly appeals come before these courts are evident when we compare Irish decisions with those of the House of Lords in the UK or England. In every case there are far more House of Lords decisions to draw on. In some areas of law in Ireland, there is widespread expectation of judicial creativity which awaits any case at all that could possibly be relevant to reach the higher courts and spark an appropriate decision. This slow turnover can easily give the impression of unchallenged judicial consistency over decades. ${ }^{28}$ Many famous statements of the higher judiciary in Ireland are in fact obiter, appearing in decisions in quite separate areas of law from those which the remarks address. A good example is Hamilton J's discussion of the judicial power to declare new crimes under the Constitution - in a civil law decision. ${ }^{29}$ As a result, general statements of principles in one case in Ireland come to do service over a wide area of law, as we saw in the example of criminal recklessness above. Northern Ireland too has a slow turnover of cases and indeed there are so few cases that one would often need to extrapolate from one case alone to predict what the practice of the judiciary might be in particular areas of law or regarding particular judicial doctrines.

In addition, if one looks more closely the consistency among judges (both in substantive law and justificatory arguments) is less complete than it may appear from the decisions of the majority. In Ireland there has rarely been a Supreme Court in which there were no aberrant judges. In the early days, Kennedy CJ opposed the judges reluctant to challenge the authority of the legislature; ${ }^{30}$ in more recent times Henchy $\mathrm{J}$ regularly held out against the activists, ${ }^{31}$ and O'Hanlon $\mathrm{J}$ in the 1990 s has fought back against the diminishing authority of traditional natural law arguments in the modern Supreme Court. ${ }^{32}$ There have been times of relative quietude but there are few cases where revolution has taken place with unanimous support. In Northern Ireland, Black LJ was notable for his sturdy formalism at a time when this approach was beginning to dissolve, ${ }^{33}$ while Lord MacDermott was a singular though not flamboyant constitutionalist and rights lawyer ${ }^{34}$

28 There has been a considerable increase in the number of cases coming before the higher courts of both Irelands in recent years and we may wonder whether this may therefore come to have wide-reaching effect on argumentation in both legal systems.

29 Attorney General (SPUC) v Open Door Counselling Ltd [1988] IR 593.

30 The State (Ryan) v Lennon [1935] IR 170. See also Towey, "Hugh Kennedy and the Constitutional Development of the Irish Free State" (1977) 12 Irish Jurist (n.s) 355.

31 See G.H., "Mr Justice Seamus Henchy" (1988) 10 Dublin University Law Journal 124.

32 See O'Hanlon "Natural Rights and the Irish Constitution" (1993) Irish Law Times 8; "The Judiciary and the Moral Law" (1993) Irish Law Times 129.

33 See his judgments in Parkinson v Watson [1956] NI 1 and Russell v Thompson [1953] NI 51.

34 See for example his judgments in O'D Cars Ltd v Belfast Corporation [1959] NI 62; McEldowney v Forde [1970] NI 37 and R v Corr [1968] NI 193. 
and several decisions display Lord Lowry's discreet talent for judicial ingenuity. ${ }^{35}$ If there were more cases and larger numbers of higher judges to draw from for a particular case, the apparent coherence over long periods of time in many areas of law in smaller legal systems might diminish.

The relative synchronic and diachronic coherence of law in the two Irish legal systems may be due as much to structural factors as to any putative comity of thought among the higher judges. In particular the combination of full court decisions, long-standing judges and long-standing decisions (not to mention the one-judgment rule which silences the Irish Supreme Court in certain constitutional cases ${ }^{36}$ ) can hardly fail to make the law of the two smaller legal systems seem more coherent than English and UK law. ${ }^{37}$

\section{(c) Relative volume of authoritative case law}

Related to the phenomenon of low case turnover is the resulting lack of authoritative case law. In 1974, the Irish jurist John O’Connor wrote:

“. . . English, Northern Ireland and Scottish decisions since 1922 enjoy such a high degree of persuasive authority that modern UK case law will be ignored by the Irish practitioner at his peril." 38

O'Connor was being too polite: the numbers of Scots and Northern Ireland cases cited in Ireland have always been tiny, except where they reach the House of Lords. Nevertheless the English decisions, while in no way binding, have in practice exercised enormous influence because the much greater volume of cases heard in England provides a useful source of developed law on most topics. Seamus Henchy, later to be a judge of the Irish Supreme Court, contended in 1962 that English decisions were to be given "that respect which their intrinsic worth may entitle them to claim" 39 but the real extent of dependence on English precedent may be gauged by more recent comments by his future colleagues such as McCarthy $\mathrm{J}$ who complained in 1992 of the "forensic forelock touching" shown by lawyers of Ireland to English law. He described this as part of a "cultural cringe" which encouraged an unanalytical dependence upon precedent. ${ }^{40}$ In Northern

35 See for example his judgments in $R$ (Hume) v Londonderry Justices [1972] NI 91; $R \mathrm{v}$ Flynn and Leonard [1972] NIJB 1 (May) and $R \mathrm{v}$ Thain [1985] NI 457.

36 See the provisions of Article $26.2 .2^{\circ}$ on Bills referred to the Court for a decision on their constitutionality: "The decision of the majority. . . shall. . . be the decision of the Court...and no other opinion, whether assenting or dissenting, shall be pronounced nor shall the existence of any such other opinion be disclosed." See likewise Article 34.4.5, except that there is no reference to the "decision of the majority" but instead to "the decision" of the Court.

37 Whether it is applied by the lower courts faithfully and in a consistent manner is of course a rather different question outwith the reach of this present study.

38 O'Connor, "The Law Reform Commission and the Codification of Irish Law" (1964) 9 Irish Jurist 14, p 26.

39 Henchy, "Precedent in the Irish Supreme Court" (1962) 25 Modern Law Review 549 .

40 McCarthy $\mathrm{J}$ in the foreword to Byrne and McCutcheon, The Irish Legal System ( $3^{\text {rd }}$ ed, 1996) ibid. Lynn has also made a tart comment about "the willingness which Irish judges have displayed to look across the water, and be influenced by 
Ireland, where the legal system is part of the UK, most areas of law are still predominantly served by English textbooks and scholarly commentaries. Judicial and academic tradition in Northern Ireland is to cite the highest or most established authority for a norm and these authorities tend to be found in English law. Conservatism in citation of cases by counsel before the court limits the choice available to the judicial panel. ${ }^{41}$ However we interpret these developments, they are again capable of exercising an inhibiting influence on the nature of judicial justification: a smaller body of national case law provides fewer precedents for distinctive judicial reasoning.

\section{(d) Legal education and training}

The way in which legal personnel, particularly judges, are trained can have a number of conflicting effects. Legal history is an important consideration here: in the British Isles full-time university degrees in law, compulsory for all legal personnel, are in some cases a relatively recent innovation. Where there has been a vocational rather than an academic approach to training legal personnel, their broad and non-specialist educational background may inhibit innovation. It might for instance undermine distinctive judicial development of the law by promoting a technical approach rather than a jurisprudential and principled one. On the other hand, it might be that such a system promotes a pragmatic legal philosophy which is less thralled to rhetorical sophistry. A generalist approach in judicial doctrine could look to policy or principle and encourage considerable development of the law. Here again the relative size of a legal system may not be insignificant. Where there is a relatively slow turnover of case law and a small number of cases doing service over a wide range of law, this might promote through necessity the development of a more broad-ranging and less detailed style of judicial decision-making and where this is found in a legal system it might have less to do with legal culture and more to do with systemic factors.

\section{(e) Juristic commentary}

A lack of juristic commentary may also affect judicial development of the law in smaller legal systems. The law journals of the two Irish legal systems occasionally carry articles about the position in the other legal system in one or other branch of law and there are books carrying contributing articles from the other legal system, but it is hard to find systematic surveys making direct comparisons between the two with an awareness of the methodological problems involved. Both legal systems also suffered for decades from a lack of legal scholarship and historical materials: only since the 1980s has there begun to be a wide selection of quality works on law in Ireland covering the majority of the legal field. McMahon pointed out in 1982 that:

what they saw. ..": "Taking the Desire, and maybe the Presumption, out of 'Intent"' (1985) 7 DULJ 73.

41 See eg Paterson, The Law Lords (1982), p 20-22 and passim. Thanks to John Bell for emphasising this point. The Lord President of the Court of Session, Lord Rodgers, has also pointed out, not entirely in jest, that the availability of photocopies hugely widened the opportunities for citation of precedents from other jurisdictions for the simple reason that it became easy for counsel to provide the judge with a copy of the case report ("Scots Law after the Constitutional Changes", seminar given at Glasgow University, 15 December 1999). 
"Partly because of the lack of Irish textbooks, partly because of the unavailability of many unreported judgments and partly because of an understandable lack of courage which springs from such chaos, the Irish bar, until comparatively recently, relied almost exclusively on English precedents not only as guides, but as authorities." 42

It is possible that this state of affairs in the island has inhibited divergent development, particularly in Ireland where independence has in other ways provided an opportunity for new principles and new argument forms to be given a tentative airing and testing. For divergence to develop and overcome this it is probably necessary that differences between Irish and English law are seen not merely as accidental or convenient but as the product of deeper differences in principle, whether in substantive law or in wider values. ${ }^{43}$ Lack of written material is not however necessarily fatal to legal development in closely-knit legal communities. In the context of judicial biography, Byrne and McCutcheon have noted that "many of the points that might form the content of such a book are passed by word of mouth, perpetuating the 'oral traditions' of Irish life." 44 This argument could be more widely made. Nevertheless, depth of reasoning over periods of time is perhaps more easily developed in the relatively meticulous practice of academic writing rather than in oral discussion.

I hope that by giving these illustrations I have said enough in this confined space to indicate that there are good grounds for the proposition that the relative size of a legal system (which of course can be measured in many ways other than by population as I have done here) produces influences on the character of its judicial pronouncements that are by no means immediately obvious and which are nevertheless of great importance in contributing both to that system's law and to the paradigms of its legal tradition.

\section{POLITICAL CULTURE AND THE RELATIVE STRENGTH OF POLITICAL INSTITUTIONS}

Another set of factors which influence the argumentation of judges is the political framework in which the legal system is set, both cultural and governmental. One area of political culture which is often particularly influential on law is nationalism. In new or small nations nationalism may

42 McMahon, "The Irish Contribution to Tort Law" (1982) 4 Dublin University Law Journal 1. More recently, McCutcheon and Quinn have referred to the two Irish legal systems as suffering "the challenges that are encountered in small jurisdictions, in particular a paucity of indigenous legal materials and comparatively scarce resources dedicated to the legal process." "Codifying Criminal Law in Ireland" (1998) 19 Statute Law Review 131. Farmer has explored similar difficulties in Scots law by way of a more critical discussion which also lays some blame at the door of the Scottish judiciary: "Debatable Land" (1999) 3 ELR 32.

43 Even this may be insufficient to promote healthy development in the law: see, as mentioned previously, Farmer's critique of essentialist presumptions in "Debatable Land", ibid.

44 Byrne and McCutcheon, The Irish Legal System (3 ${ }^{\text {rd }}$ ed, 1996), p 129. 
be of huge importance in developing a civic culture and reinforcing infant institutions of the state.

\section{Politicisation of nationalism and cultural identity in the legal system}

The influence of nationalism, both in political ideology and in the sense of a cultural differentiation from other nations of the British Isles, has contributed to a distinctive tradition in the constitutional law of Ireland since independence. Even the parliamentary model of Ireland, in many ways as British as it is North American, is not invariably discussed with reference to its UK origins. While counsel and the judiciary in the ordinary run of things look to English and UK law for decisions in substantive law, to the extent that the higher judiciary regularly criticise the legal profession for being uninventive, ${ }^{45}$ and while legislation in Ireland is often drawn or copied from English legislation, ${ }^{46}$ legal discourse in Ireland frequently encourages a strong conceptual separation between the two systems which may not accurately reflect the degree of distinction in everyday matters in ordinary legal practice. ${ }^{47}$

The higher judiciary too, over a formative period in Irish constitutional law of around twenty years since the 1960s, has tended to draw on sources of fundamental principles which are seen as belonging to humanity (whether or not religious in origin) rather than originating from the English common law. One exception to this is where judges have been inclined to refer to an early common law personified by Coke in a pre-Benthamite incarnation which appeared to ally the common law with natural law.48 This however has allowed a selective appropriation of particular features of the common law tradition which are then represented as in some way the indigenous law of Ireland. This select historical focus permits an appeal to tradition while diminishing the importance of most of the English legislation still in force in Ireland, since this was enacted in the $19^{\text {th }}$ and $20^{\text {th }}$ centuries. ${ }^{49}$

Whatever the reality of this ideological picture, it is plain that members of the higher judiciary have helped establish it. Here law and culture have

45 See eg McCarthy J's foreword to Byrne and McCutcheon ibid and Walsh J's foreword to Tierney, Irish Trade Marks Law and Practice (1987).

46 See for example the Trade Marks Act 1963 which is almost entirely identical to its 1938 English counterpart. McWilliam J referred to this type of practice as "the scissors and paste penchant of our Legislature" in Breatnach $\mathrm{v}$ McC [1984] IR 340,346 , quoting Black J. Kelly suggests that such statutes or parts of statutes should be permitted a weaker presumption of constitutionality since they have been designed to fit a system with no constitution similar to that of Ireland and so unconstitutional elements may slip through: Hogan and Whyte, The Irish Constitution ( $3^{\text {rd }}$ ed, 1992), p 453.

47 See $e g$ the arguments in Hogan, "Irish Nationalism as a Legal Ideology" (1986) Studies 528.

48 A case frequently cited in Irish commentary is Dr Bonham's Case (1610) 8 Co Rep 107a. Coke's remarks, notably, are cited without reference to their political context, which reflected the precariousness of judicial independence in the $17^{\text {th }}$ century, and for which Coke was later sacked. See further Loveland, Constitutional Law: A Critical Introduction (1 $\left.{ }^{\text {st }} \mathrm{ed}, 1996\right)$, pp 71 and $104 \mathrm{ff}$.

49 See eg Costello, "The Natural Law and the Irish Constitution" (1956) Studies 403. 
interacted and the prime source upon which they relied to build conceptions of uniquely Irish law has been their powers of constitutional review under the Constitution.

While nationalism in Ireland has promoted judicial divergence, it has had the opposite effect in Northern Ireland. The religious heterogeneity of Northern Ireland, which today has a population of 56\% Protestants and $40 \%$ Catholics $^{50}$ is to a great extent reflected in a related political division between republicanism and unionism. Because nationalism is typically associated with the Republican minority grouping in Northern Ireland, and because that grouping is sizeable and has support in Ireland, a nationalist stance of any kind is much more controversial than it would be in Ireland. This may play a part in legal and social attitudes towards any belief that a distinctive Northern Ireland law might be necessary or desirable.

Obviously nationalism in the sense of state sovereignty is a political doctrine associated with the Nationalist minority, but cultural nationalism also appears to be associated with this political grouping, in contrast to the role which cultural nationalism occupies in Scotland or Wales, where cultural nationalism is relatively (albeit not entirely) independent of political commitment to national independence. Nationalism in Northern Ireland is therefore unavoidably politicised and it is likely that it is more difficult for Northern Ireland judges to shore up divergent or dynamic decision-making with references to the unique character of the legal system. A national cultural identity has also been retarded by the fear of the Unionist community that such an identity would drive it away from the close relationship with the UK and so facilitate the reunification of the island. There appear to have been few public calls by members of the legal profession for a Northern Irish law either in general or in any specific field of law: such debate is notable by its absence from the legal journals. Here again in both Irelands we see a cultural background which has substantial potential to influence the ways in which judges justify their decisions.

Nationalism is however not just a cultural or attitudinal phenomenon and it is influenced by many variables. To give only one example in the legal context, there may be a stronger sense of national identity in areas of law which are clearly separated by national boundaries. In the wider island of Ireland in the centuries before independence there was considerable resistance to the English legal influence and even after the common law eliminated its local challenger, certain areas of law such as family and land law remained distinctively Irish (divorce statutes for example were never extended to preindependence Ireland). ${ }^{51}$ In tort, contract and land law a practice has continued of citing cases from the other Irish legal system, so that the English precedent has had a diminished influence. Where the English and Irish jurisdictions have been kept separate in a particular area of law (such as

50 Continuous Household Survey 1995-96. 3\% stated that they were brought up under no religion; $1 \%$ gave no answer. Less than $1 \%$ was brought up in a different Christian or other faith.

51 See Sheehy, "The Right to Marry in the Irish Tradition of the Common Law" in O'Reilly, Human Rights and Constitutional Law (1992), p 19. The right to divorce was introduced following a referendum on amendment to the constitution in 1995 . 
land law), or in areas of law where reasoning tends to be case-to-case and precedent is less likely to lay down principle (as in the interpretation of provisions in wills and trusts, ${ }^{52}$ in sentencing or in the calculation of damages), it is plainly easier for judges to develop substantive divergence without needing to frame it in the language of doctrinal divergence. Thus, while nationalism is a potent phenomenon in legal development, we need to be careful when we identify its presence in judicial decisions because the precise nature of its significance may be difficult to divine.

\section{Distribution of power between the executive, the legislature and the judiciary}

Another important political factor in forming the character of judicial justification can be the relative power possessed by the different organs of the state. Much of the development of judicial activism in Ireland, for example, has been promoted by force of circumstance due to a weakened legislature. The country's system of proportional representation has tended to lead to coalition governments and there have been twenty-eight parliaments since independence. Because the Oireachtas has declined to act on identified problems, individuals have brought cases before the courts which have led the judiciary to make decisions which could have been made by the legislature. In contested areas of morality, in particular, the domestic legislature has been very slow to respond. The courts have taken the first step and the Oireachtas has followed - often very belatedly. ${ }^{53}$ This weakness had the effect of creating lacunae in the formal vision of law in Ireland. A formal vision of law relies upon a strong legislature that responds quickly to a perceived need for well-drafted legislation. The failure to legislate placed pressure on the higher judiciary to fill in the gaps and so encouraged a secondary substantive vision of law to be developed by the judiciary in order to legitimate what in some cases was judicial legislation.

In strong contrast, the UK legislature has provided legislation in Northern Ireland in many of the areas in which the Supreme Court was forced to create law in Ireland. Northern Ireland has suffered from the combined problems of an undemocratic legislative process at Westminster and an unrepresentative legislature at Stormont. ${ }^{54}$ There are many complex reasons for the slow

52 In Heron v Ulster Bank Ltd [1974] NI 44, 52, reference was made by Lowry LCJ to the lack of binding precedents because "No will has a twin brother."

53 Significant examples are easy to find, even after the problems have reached the higher courts. The Eighth Amendment on abortion was inserted in the Constitution in 1983 but despite a long list of notorious cases which went to the Supreme Court and Europe, no statute was enacted to regulate any of the issues on abortion until the Regulation of Information (Services Outside the State for the Termination of Pregnancies) Act of 1995. Even then, the statute only dealt with one small area of the problem. Norris v Attorney General [1984] IR 36 on the criminality of homosexuality reached the Supreme Court in 1983 and went on to the European Court of Human Rights in 1988 (Norris v Ireland (1988 13 EHRR 186) but the Oireachtas failed to act under its Convention obligations until it passed the Criminal Law (Sexual Offences) Act of 1993.

54 Until the transfer of legislative functions to the new Northern Ireland Assembly in 1999, the process was carried out by the application of some Westminster Acts to Northern Ireland while local "statutes" were created by Orders in Council. This latter process did not permit the extent of debate which is available for other UK 
development of a participatory political culture in Northern Ireland but however one explains it the result has been a dearth of litigation providing the opportunity for judicial activism and thus distinctive examples of judicial justification. Without cases, judges are partially silenced. While constitutional and then, later on, rights cases were regularly litigated before the courts of Ireland from the 1930s onwards, the law reports of Northern Ireland show a gaping void. Hadden and Hillyard have pointed to "the failure of civil rights leaders" before 1968 to encourage litigation against systematic discrimination by the administration in the distribution of public spending, the allocation of housing, appointments to local government and the gerrymandering of boundary divisions. ${ }^{55}$ The judiciary was thus denied for many years the opportunity to develop a judicial response even though there was scope to do so. It was not until the emergency powers cases of the 1970s that the courts began to play a significant part in developing rights in Northern Ireland. It was in the nature of these cases (mainly in the area of the law of evidence) that the effect on rights doctrine in law was incremental rather than radical, albeit that the practical effect was at times substantial. Overall, in the fields of constitutional law and human rights, Northern Ireland has lacked activist litigators as much as it could be said to lack activist judges.

Political culture and the strength of political institutions, then, play their own part in creating a legal culture and opportunities for the development of particular forms of judicial justification. We could not begin to make an enlightening comparative study of constitutional reasoning by the judges of the two Irelands without first comparing these political factors.

\section{The social and political context of judicial roles}

At the beginning of this article I emphasised the need to examine major structural differences between legal systems. The patent differences between the political and economic status of different nation-states and the constitutional position of their judiciaries make it essential to contrast the place of the judge in each legal system before attempting to make any assessment of the character of judicial justification. A judge's decision to extend (or contract) the law in a particular case may have as much to do with conceptions of legitimate authority in that legal system and that area of law as it has to do with nebulous "personal" characteristics like liberal political views or an anti-authoritarian disposition. What amounts to a legitimate exercise of discretion in any one legal system depends on formal constitutional factors and also legal-institutional and social perceptions which may have come about by informal means. Judicial caution in a devolved territory does not necessarily imply conservatism, just as activism in an independent nation-state does not necessarily imply a disregard for the

statutes and indeed for those which were applicable solely to Scotland before devolution. Rather, the Northern Ireland legislation was made in a procedure used for delegated legislation. See also the criticisms voiced by, among others, Dickson, "Northern Ireland's legal system - an evaluation" (1992) 43 NILQ, p 316, Hadfield, The Constitution of Northern Ireland (1989), p 101 and Maguire, "Parliament and the Direct Rule" (1975) 10 Irish Jurist.

55 Hadden and Hillyard, Justice in Northern Ireland: a study in social confidence (1973), pp 8-11. 
separation of powers or a careless lack of precision. Both relate much more strongly to systemic political and ethical doctrines and need to be understood in that broad context.

Even in paired states such as Northern Ireland and England where there is to a greater or lesser extent a shared legal system, there are essential differences beyond the obvious distinctions such as political status and constitutional frameworks. Where these features can be found in many advanced legal systems, they should be identified and categorised. Below, I have outlined one possible transnational index of variables constructed out of those suggested by several political scientists and legal philosophers. ${ }^{56}$ Precise measurement of many of these variables would require sophisticated research (and in some cases would barely be possible) but even a preliminary investigation provides us with very useful insights into differing judicial roles.

\section{Judicial capacity to carry out constitutional review}

Here we can contrast judiciaries which possess an original power of review that is independent of the legislature and judiciaries whose ability to review ordinary or constitutional law is delegated to them by an exercise of power by the legislature. The latter are to some degree constitutionally excluded from the wider debate on the nature of the authority of law in that legal system. Such a judiciary in a common law legal system such as England's may perceive itself as possessing in most areas of law not so much an original power as, in fact, little more than a residual power: that which it has brought from the common law untouched by statute, and that which is left by the need to interpret the provisions of the other organs of the state.

For the sake of isolating the point of argument I disregard here, for the moment, the obviously significant power of review possessed by the English judiciary in European Community law or under the Human Rights Act. I also disregard the possibility of a different approach to constitutional interpretation in those legal systems affected by constitutional statutes of devolution, such as Scotland. There was a nascent tradition of constitutional interpretation in Northern Ireland before the Stormont government was

56 It is difficult to cite each individual contribution separately as I have modified and amalgamated some, while other categories were suggested by several authors in varying contexts. The composite framework is taken in particular from suggestions made by the following: Tate, Schmidhauser and Schubert in Schmidhauser (ed), Comparative Judicial Systems (1987) (Tate's chapter is an excellent critical survey of a number of frameworks from political science) and Schneider and Bell in Hawkins, The Uses of Discretion (1992). Assistance also came from Posner, Law and Legal Theory in the UK and USA (1996); Sunstein, Legal Reasoning and Political Conflict (1996) ch 7; Gwyn in Franklin and Baun, Political Culture and Constitutionalism: A Comparative Approach (1995) and Atiyah and Summers, Form and Substance in Anglo-American Law (1987). Classic sources which exert a general influence on anyone working in this field in the UK and beyond include Griffith, The Politics of the Judiciary $\left(5^{\text {th }}\right.$ ed, 1997), Paterson, The Law Lords (1982) and the wealth of work by Robert Stevens, including most recently "A loss of innocence?: judicial independence and the separation of powers" 19 Oxford Journal of Legal Studies, pp 365-402.

Byrne and McCutcheon, The Irish Legal System (3 $3^{\text {rd }}$ ed, 1996) provides the answers for Ireland to a great many questions which these frameworks raise. 
prorogued which can be seen in the statement of Lord MacDermott in O'D Cars Ltd v Belfast Corporation. ${ }^{57}$ This declaration entered into a small place in Northern Irish constitutional history and was cited for instance in the recent decision of In re Perry. ${ }^{58}$

One would expect that this perception would influence judicial views on what constitutes legitimate creativity or activism. Furthermore, in a legal system in a devolved territory, the more subordinate status of the highest domestic judiciary, and the greater legal and political disincentives discouraging them from judicial legislation, may create a set of roles which is much less likely to lead to radical acts of judicial activism. Openings may very well remain for creativity and activism in such legal systems, though, and we should not overlook the possibility of structural opportunities appearing at particular times in particular fields of law.

To some extent judicial creativity is not only unavoidable but also desirable in most if not all legal systems. Nevertheless there are of course genuine constitutional questions raised by what some regard as the misappropriation of democratic powers where judges are unelected, and in any legal system there will be a balance to be found between judicial creativity and limitation on the delegation of power to the judiciary as one organ of the state. There are also considerations of suitability to the task and again it is a truism to point out that the courtroom is not always the best forum for debate leading to social change, albeit that it may be the best available forum in that area of law in that legal system at that particular time. When evaluating what is seen to be legitimate activism in any particular legal system, the prevailing concept of the nature of democracy is relevant. In England, where the traditional paradigm is one of parliamentary democracy, John Bell has argued that the English judiciary, while giving clear legislative statements precedence over individual human rights, retains some powers of creativity in all areas of law and will attempt, at times ingeniously, to interpret statutes instrumentally in accordance with policies of the legislature. What is important is that these are express legislative policies rather than independent judicial policies: English judges are more comfortable with advancing policies which have been promoted in existing legislation than with independently pursuing substantive objectives. The former approach carries the security of the legal mandate by emphasising consistency with the wider law, while the latter risks being seen as capricious.

Bell maintains that English judges view themselves as possessing their strongest powers of creativity first within the common law where they have historically had a central role in developing principles, and second within what Bell calls "nightwatchman" areas of law such as "the protection of public order, the prevention of crime and the defence of national security". They will also protect basic procedural rights and guard the jurisdiction of the courts by robustly fending off legislative or executive encroachment. ${ }^{59}$ They are much less willing to be dynamic in substantive areas of law where the legislature has developed that law to its present state, or where they are

57 O'D Cars Ltd v Belfast Corporation [1959] NI 62, 87.

58 In re Perry (LEXIS report) 19 April 1996 (QBD).

59 Bell in J. van Dunné, Legal Reasoning and Statutory Interpretation: Rotterdam Lectures in Jurisprudence (1989), p 78. 
being asked to implement social objectives that have not been expressly stated by the legislature. They have also been reluctant to be seen as usurping the legislative function in areas of law which are controversial, whether morally or politically. It will be interesting to see how these roles are adapted to accommodate the uncertain range of powers conferred by human rights and devolution legislation.

In Ireland, while the institutional role of the higher judge in Ireland differs significantly from that in England, particularly in matters deemed constitutional, the dynamic powers of even the Supreme Court should not be exaggerated. The 1937 Constitution was not designed with the intention of creating Solomonic judges and de Valera felt that judges should not make policy or radically develop the law. Indeed he is said to have had "a considerable suspicion of the judges because of their origins and their traditions." 60 Nevertheless the classic Irish theory of popular democracy, which represents the Constitution as the expression of the will of the people, makes it simple for judges in a wide range of cases to appeal to constitutional mandate rather than discuss the less easily-defended issue of judicial creativity by itself.

Concepts of constitutional review, then, may be (or may be traditionally seen to be) the product of judicial reasoning rather than political direction. Nevertheless as we have seen this does not mean that we can simply identify the concept as "conservative" or "traditional" or "anachronistic" or "modern" and then presume that the judiciary who created it fit that profile too, however many cases we might cite to justify the argument. The constitutional setting and the political ideologies of a state may at a deeper level be the primary source of the limits of constitutional review.

\section{Depth of rule adjudication}

Another aspect of what amounts to or is seen to go beyond legitimate activism is the extent to which rule adjudication is permitted to go beyond the individual case. While authoritative decisions lay down binding rules, this process is not of course equivalent to a legislative process and the courts do avoid laying down general principles governing the law beyond the issues raised in each case. In some areas of law (such as parts of the law of evidence in England and the two Irelands, for example) the distinction is particularly clear and the judiciary are very unwilling to extrapolate from the facts of particular cases. However HLA Hart's assertion that "the judge's powers are exercised only to dispose of particular instant cases" 61 does not encompass the full range of judicial powers. In areas such as constitutional law, judges may assert the right to look more widely than the particular question in consideration. In the Irish case of O'Brien v Keogh, for instance, the Supreme Court held:

". . . when a question arises as to the unconstitutionality of a statute, the courts' duty is to test the provision widely, away

60 Chubb, The Politics of the Irish Constitution (1991), p 118.

61 Hart The Concept of Law (2 ${ }^{\text {nd }}$ ed, 1994) postscript, p 273. 
and beyond the problem presented by the circumstances of the particular case". ${ }^{62}$

As we have seen above, the fact that judges do or do not claim that they possess such rights is not necessarily an indicator of their political opinions, but it does provide other insights for comparative study, particularly where the researcher is attempting to identify the extent to which particular judges have in fact been activist or conservative in the context of their own legal system.

\section{Formal independence of the judiciary}

Here we would examine the extent of the formal separation of powers between the judiciary and the other organs of the state, and the extent to which this is protected by entrenched norms. As an example of how this might have a significant effect on the development of law, we could consider the question of the means of making judicial appointments. Political involvement in selection of judges would be significant but to what extent it was significant would depend on the character of government in that political system. We would consider many factors: how long the appointees stayed in post, influencing the character of law over a period of time; how large the body of higher judges was and so how important one individual appointment might be; whether the appointment took place during a period of social or legal change, during which a particular panel of judges might have a disproportionate influence on the future direction taken by the law; whether any resulting loss of confidence discouraged litigants from bringing forward important legal issues for consideration by the courts, and so forth. We can see that in any one aspect of judicial independence, there could be a sizeable number of variables to analyse.

\section{Effective scope of rule adjudication}

If there is formal or indirect censorship of the judicial agenda then there may be a range of fundamental concerns which are in practice left beyond the powers of the judiciary, whatever their formal powers. In Northern Ireland in the 1960s, as we saw above, reluctance to bring civil rights actions in the courts during the 1960s meant that the power of judicial review was effectively greater in law than it was in fact. ${ }^{63}$

\section{Compliance with judicial orders and respect for judicial authority by other organs of the state}

The extent to which judicial independence is in practice respected by other organs of the state will very likely be influential on the character of judicial justification in politically sensitive cases. This is obvious but easily overlooked by later commentators, particularly when the battle was later resolved and did not lead to serious unrest, civil war or revolution. In the

62 O'Brien v Keogh [1972] IR 144 at 157-58. This right is arguably implied in the Irish Constitution because Article 26 grants the Supreme Court the right to pass judgment on the constitutionality of bills and provisions of bills which have not yet been enacted.

63 For a discussion of this reluctance see Hadden and Hillyard, Justice in Northern Ireland: a study in social confidence (1973), pp 8-11. 
early days of the Irish Free State, for instance, there was dangerous conflict over the separation of powers in response to actions of the executive and the concern of the judiciary is visible in several decisions from that time. ${ }^{64}$ It is generally maintained by legal commentators in Ireland that there was a lack of judicial activism before the 1960s in Ireland but this is commonly put down, a little unfairly, to judicial conservatism. ${ }^{65}$ Insufficient notice seems to have been given in modern times to the problem which the early Supreme Court faced in defending the Constitution against the usurpation of power by the Oireachtas. ${ }^{66}$

On a rather more indirect level judicial independence can be threatened by the tasks which judges are handed by the state, as where the state is divided by conflict over moral issues such as reproduction, or political issues such as a powerful anti-state element, as in Northern Ireland. Any ideology of judicial neutrality is then threatened and, to the extent to which the social authority of the judiciary depends on this ideology, judicial independence may be weakened. As we have seen, Irish judges have been forced to adjudicate on contested areas such as abortion which have been evaded by the legislature, while in Northern Ireland the covert politicisation of the role of the judiciary has been even more extreme. Sean Doran and John Jackson have pointed out that the decision by the UK government to use the ordinary criminal justice system (particularly since the mid-70s) rather than a separate system of martial law and courts to control terrorism resulted in the Northern Ireland judiciary attracting criticism as a result of the outcomes of controversial cases. The judiciary in their view has run the risk of being identified with unpopular decisions regardless of the quality of the decisionmaking involved ${ }^{67}$ Concerns regarding the political repercussions of judicial interpretation of the devolution statutes and the Human Rights Act in the UK are not unjustified.

\section{Independence of the judiciary from other powerful groupings}

It would be attempting too much to speculate on the covert influence exercised by economic and social elites in any medium-scale piece of research into legal phenomena. It might however be worthwhile examining some more explicit forms of interference by powerful groupings. In Northern

64 See: Ryan v Lennon [1937] IR 170; Re the Estate of the Earl of Mountcharles [1935] IR 163 (Sup. Ct) in which compulsory land purchase was made with only the most obscure "notification" to the residents; Hughes v Lennon [1935] IR 128 in which a military tribunal asserted a right to try an offence, in disregard of the Constitutional right of habeas corpus and The State (O'Duffy) v Bennett [1934] IR 70 in which the Attorney General asserted that a military tribunal had been given apparently unlimited powers, including capital punishment without judicial review.

65 See eg Kelly's comments: "The older generation of judges consisted of cautious men with a modest view of their own status vis-à-vis the legislature, and slow either to invalidate what the legislature had done or to take it on themselves to supply what it had left undone." (Hogan and Whyte, The Irish Constitution ( $3^{\text {rd }}$ ed, 1992), p xci.

${ }^{66}$ For an interesting and contrasting view, written at the time, see the anonymous contribution to 2 Northern Ireland Legal Quarterly (1942) 84.

67 Doran and Jackson in Dawson and Ingram, One Hundred and Fifty Years of Irish Law (1996), pp 70-71 and 94-95. 
Ireland, for instance, it is not unreasonable to argue that the continuing violence $^{68}$ is very likely to encourage the judiciary to be circumspect in voicing any opinion which might indirectly give support to one or other of the warring communities. Five members of the Northern Irish judiciary have been murdered by the IRA, the last of whom was a (relatively) outspoken judge, Lord Justice Gibson, in 1987, while in 1997 the RUC confirmed that personal details of Lord Hutton, the then Lord Chief Justice, had been found within a suspected IRA intelligence cell and the judges were warned that they were the object of renewed surveillance at that time in the wake of failing peace talks. Threats made against RUC officers may indicate that the judiciary is not immune from loyalist threats either. Judges at all levels and their families remain under heavy guard. ${ }^{69}$ The recent (selective) ceasefires and political settlement are undoubtedly too recent and insufficiently stable for anyone to be certain that this type of threat to judicial independence has declined.

Identifying the actual effect of interference is more difficult but it is perhaps better to make the attempt than to ignore such an important variable altogether (albeit, admittedly, that misguided claims to explanation can lead future research astray and by so doing provide more of a brake than a contribution).

\section{Cross-cultural representation within the judiciary}

Accusations of economic and social elitism within a judiciary would, again, be difficult to substantiate without considerable empirical research. At a gross level of analysis, though, the social homogeneity of the judiciaries is evident in many legal systems. In many systems there are only a few universities which provide qualifications accredited by the governing bodies of legal personnel and in Ireland and the UK the traditional barrister/advocate route to becoming a judge has been financially inaccessible for the great majority. Family relationships between judges and other higher legal (and political) officials are often a quick clue to the possibility of homogeneity. Class, race, religion and gender are all indices which give a incomplete but useful indication of the social diversity of the judiciary in different societies and as long as some effort is made to control for major variables (such as the degree of homogeneity in the whole society) they can help to provide raw material for the development of future hypotheses in this area of research.

\section{Method and standards of judicial selection}

Some legal system operate with rather opaque processes of evaluation, even where they have gone so far as to provide independent or partially independent appointments boards. Even at the most innocent level, cautious methods of selection may result in cautious judges. The remuneration given

68 During the Nineties, deaths and injuries directly attributed to the security situation ran at slightly under a thousand per year, with a total of over 37,000 between 1969-95. NI Annual Abstract 1997.

69 See also on a related topic Doran and Jackson in Dawson and Ingram, One Hundred and Fifty Years of Irish Law (1996), p 77. 
to the judiciary, too, in comparison to other members of the legal profession, may affect the quality and perhaps the courage of judicial reasoning.

\section{High levels of support / social legitimacy}

Some states carry out social surveys which measure variables like confidence in the criminal justice system, ${ }^{70}$ while social scientists may measure confidence in particular areas of law or particular geographical areas of the state $^{71}$. This hints at the social support which judges may or may not be able to draw on when dealing with public and controversial legal issues: one does not need to undertake a particularly extensive survey of the literature in Northern Ireland for instance to discover that the higher judges have been criticised both for using their creative powers to protect civil liberties ${ }^{72}$ and for not using their creative powers to protect civil liberties. ${ }^{73}$

\section{Security of tenure and protection of employment conditions}

Here, we would look to the existence or otherwise of lifetime tenure, protected by an entrenched norm. We would also consider the ease by which and the conditions in which judges could be removed from office in a legal system. As with many of these variables, we need to consider not only the current norms but legal history too. A legal system may possess few entrenched norms but have no history of judicial impeachment and little history of pressure on judges to resign (other than for "personal" reasons, however we might choose to define these). This can work both in the interests of democracy and against it, as where corruption in the legal profession is known to be safe from formal investigation.

As regards employment conditions, we could consider for example the entrenched protection of (index-linked) judicial salaries, immunity from suit, powers to declare contempt of court where there is interference with the administration of justice, and formal protection of court structure, court procedure or court business. An important concern is the protection of the right of individual judges to hear sensitive cases.

\section{Judicial influence outwith the courts}

In many legal systems senior judges may exercise a formal influence outwith their role in the courts. This may include chairing law reform bodies and other quasi-governmental organisations. Their informal influence may include participation in public debate, in academic and civil service forums

70 Northern Ireland for example has a regular Community Attitudes Survey while Britain has a Social Attitudes Survey.

71 In Northern Ireland see Hogan and Walker, Political Violence and the Law in Ireland (1989), p 109, citing Moxon-Browne, Nation, Class and Creed in Northern Ireland (1983), p 144 and Doran and Jackson in Dawson and Ingram, One Hundred and Fifty Years of Irish Law (1996) for a consideration of other, similar findings.

72 See eg the Diplock Report: Report of the Commission to consider legal procedures to deal with terrorist activities in Northern Ireland. (1972) Cmnd 5185, para 87.

73 See $e g$ the chapters by Greer and Walsh in Jennings, Justice Under Fire $\left(2^{\text {nd }}\right.$ ed, 1990), pp 78-79 but $c f$ Hogan and Walker (1989) above, n. 69, pp 125-126 and Dickson in Hadfield, Northern Ireland: Politics and the Constitution (1992). 
and in governmentally-sanctioned initiatives which impact on the structure of the legal system. They may in contrast lack power where there is a convention that judges remain silent outside the courtroom or where controversial inquiries are chaired by other senior officials. ${ }^{74}$

\section{Inquisitorial involvement in norm- and fact-determination in the courtroom}

Here we could examine not only traditional inquisitorial practices in those legal systems in which this is part of the judicial role, but also more informally the availability, if any, of legal research assistants or a tradition of making independent findings, in all areas of law or in areas of law marked by social or political controversy.

\section{Availability of dissent in multi-judge hearings}

In some legal systems, dissent is an accepted and important element of judicial reasoning in multi-judge hearings and may be a conduit for future legal change or the expression of oppositional political or social opinion. Dissent may be formally permitted while being covertly stifled. It may be available in some areas of law and not in others, as in Ireland where a onejudgment applies in decisions on the validity of laws under the Constitution in Article 26.2.2 ${ }^{\circ}$ and Article 34.4.5 ${ }^{\circ}$. Here, dissent, within (or outwith) the courtroom, is forbidden. Such rules may be unpopular and the researcher will need to ascertain the scope of this rule in practice: in Ireland it has been minimised by the Supreme Court, which claimed for instance in The State (Sheerin) v Kennedy ${ }^{75}$ that a law passed by a legislative body prior to the Oireachtas created in 1937 was not in constitutional terms a "law".

In contrast, judges may impose such conditions on themselves, as in common law legal systems where members of the supreme court decide that stability of precedent is essential to promote certainty in the law and so choose to minimise their dissenting comments. ${ }^{76}$

\section{CONCLUSION}

In this article I have listed a broad range of variables which can help to provide a political and constitutional context for analysing the significance of judicial justifications outwith the ascribed frame of the point of law under consideration. Some would require sophisticated juristic or social scientific analysis to evaluate them effectively, while others require only a quick glance at statistics provided by government departments. Together, they provide an opportunity to move beyond impressionistic evaluations of what a particular decision or body of decisions "means" in a society. I do not claim to have suggested a complete typology of variables and I do not suggest that any one theorist or researcher need feel obliged to examine them all. Nor should I pretend that a mere list of factors, accompanied by one or two

74 In Northern Ireland, for instance, controversial inquiries have traditionally been chaired not by Northern Irish legal personnel but by English judges, such as Lord Scarman, Lord Diplock, Lord Widgery, Lord Lloyd and Lord Saville.

75 The State (Sheerin) v Kennedy [1966] IR 379, 388.

76 See for example the Irish decision of Finucane v McMahon [1990] 1 IR 165. 
preliminary propositions, is sufficient to constitute a comparative method in itself. Much more work needs done. I do however believe that, meanwhile, we could be more explicit in stating those variables which we have not investigated when we write commentaries on the significance of judicial statements, thus leaving at the very least a trail of crumbs which others can follow back to find our hidden unstated assumptions. Social science has much good work to do in examining the roles of the judiciary and those currently engaged in the task on the legal front could do a little more to assist. 